\title{
MEMORIAL SOBRE A TRAJETÓRIA ESCOLAR BÁSICA DE MARLÚCIA GOMES DOS SANTOS
}

\author{
Marlúcia Gomes dos $\operatorname{Santos}^{1}$
}

Resumo: O presente texto trata do memorial sobre a trajetória escolar de Marlúcia Gomes dos Santos, ex-integrante do Programa Conexões de Saberes. Tem como objetivo apresentar os passos percorridos desde o início da educação básica até a entrada à UFPA e quais os principais entraves de estudantes das comunidades populares adentrarem o ensino superior público. A memória foi usada como principal referência para construção do material. Em seus resultados, apresenta os esforços individual e coletivo para que de fato a educação seja uma questão de direito e não de privilégio de poucos.

\section{Identidade}

Chamo-me Marlúcia Gomes dos Santos, tenho 24 anos, nascida e criada no município de Breves, localizado na ilha de Marajó no estado do Pará, sou filha de ribeirinhos, Martinho e Euzalina que vieram para a cidade em buscar de uma vida melhor, tenho 4 irmãos.

Minha vida familiar nunca foi muito tranqüila meus pais não são pessoas tão carinhosas e atenciosas como eu gostaria. Bom, desde que eu me entendo por gente há briga em minha casa minha mãe até já saiu de casa uma vez, mas para nossa felicidade ela voltou. Meu pai é violento, já expulsou de casa minhas três irmãs. Hoje quem mora com eles é meu irmão e eu, a neném, minha irmãzinha de criação e um sobrinho. Ele também já expulsou a mim e ao meu irmão, mas não fomos não fui por que não tinha pra onde ir, do contrário teria saído daquela casa. As más lembranças rondam minha cabeça, dentre elas a do meu pai tentando furar a minha irmã Márcia com uma faca na rua; eu deveria ter uns três ou quatro anos.

Quando eu paro pra pensar nos meus pais, na minha família eu não consigo lembrar de coisas boas, eu só lembro de brigas, mágoas, cobranças; meu pai é daquele que quando sabe que a filha está grávida expulsa de casa, minha mãe até chegou a dar um filho da minha irmã Mara por que meu pai não queria a criança em casa. Ele nunca deixou faltar nada para a nossa sobrevivência, mas eu preferia ter passado fome a não ter tido amor, carinho, compreensão e apoio, pois se isso tivesse acontecido meus irmãos não estariam passando por tantas necessidades hoje.

O último fato triste foi a morte do meu único irmão, ele se matou, é uma dor tão grande e parece que nunca vai ter fim. Talvez o seu suicídio tenha sido o reflexo da

\footnotetext{
1 Acadêmica* de Ciências Naturais da Universidade Federal do Pará, Campus Breves, e-mail: conexoesmulticampi@yahoogrupos.com.br

* atualizado pela última vez em 2008.
}

Revista PET Interdisciplinar e Programa Conexões /UFPA On-line. Ed. Especial - 2017, BELÉM/ PA - ISSN 2447-097X 
desestrutura que se encontra a minha família.

Mais qual a causa dessa desestrutura familiar? Educação? quem sabe se meus pais tivessem tido a oportunidade de estudar e ter o mínimo de educação tudo tinha sido diferente.

\section{Trajetória escolar}

A minha trajetória escolar foi tranqüila, com exceção de que na $7^{\mathrm{a}}$ série que eu fui reprovada. Sempre fui esforçada, mas naquele ano encontrei um professor linha dura, daquele que quanto adora reprovar. Quando fui cursar o ensino médio havia apenas duas escolas com ensino médio e optei por aquela em que aquele professor não dava aula, era a Escola municipal Maria Câmara Paes. Quando eu estava cursando o $2^{\circ}$ ano, o tal professor passou a lecionar na escola e voltei a ser aluna dele, felizmente dessa vez eu não fiquei reprovada. Quando terminei de cursar o ensino médio no ano de 2001 meu pai me perguntou se eu iria fazer o vestibular, disse então que eu ainda não havia pensado nisso, que eu nem sabia o que aquela palavra significava, pois conhecia poucas pessoas que haviam ingressado na universidade, depois resolvi tentar, mas não passei.

\section{Experiência Nova.}

Em 2000 uma amiga me convidou para entrar em um grupo de jovens, chamado Santo Agostinho, que funcionava em um colégio que tinha o mesmo nome, e como coordenadora a irmã Margareth, diretora do colégio. Conheci várias pessoas fiz muitas amizades e também perdi algumas, entre elas uma de 7 anos que me faz muita falta . Foi neste grupo que conheci uma pessoa muito especial em minha vida, meu namorado. Ao mesmo tempo em que eu estava perdendo a amizade de uma pessoa muito importante pra mim, Nara, por uma simples fofoca, ele apareceu e foi meu apoio e ainda é, pois fizemos seis anos juntos e se Deus quiser vamos fazer muito mais.

O grupo de jovens me ensinou muitas coisas, temáticas como o da realidade dos jovens, temas religiosos eram debatidos, nós éramos levados a refletir e expor nossa opinião. Quando um jovem se afastava do grupo íamos até sua casa pra resgatá-lo de volta para o grupo. Antes de participar do grupo eu era uma pessoa tímida que não sabia se relacionar como outras pessoas, e lá eu aprendi a me socializar com vários tipos de pessoas, e ao mesmo tempo falar em público e respeitar a opinião do outro. E isso pra mim foi um grande passo, pois a partir disso me tornei uma pessoa mais crítica e participativa enquanto cidadã. 


\section{Tempo ocioso}

Depois que terminei o ensino médio ter tentado o vestibular e não passado fiquei um bom tempo sem ocupação, vi o tempo passando e não sabia o que fazer pensava que o ensino médio era suficiente para conseguir um emprego, mas o emprego não aparecia. $\mathrm{O}$ máximo que consegui foi ganhar um dinheiro durante uns dois anos trabalhando de babá.

Às vezes aparecia curso do tipo secretariado, RH e economizava para poder fazê-los, achando que esses cursos ajudariam a entrar no mercado de trabalho. Cheguei até fazer um curriculum e deixá-lo em alguns locais, mas a primeira coisa que perguntavam era se tinha experiência! Mas como se nunca tinham me dado uma oportunidade!!!.

\section{Oportunidade}

Um dia meu pai chegou e perguntou por que eu não fazia cursinho? minha reposta foi, e vou pagar com que dinheiro? eu não tinha emprego fixo e o que eu ganhava como babá não dava nem para a matrícula, ele disse, então que pagaria. Naquele mesmo instante procurei um cursinho e me inscrevi. As aulas eram apenas no horário noturno, mas quando, eu chegava da aula por volta das onze horas da noite dava uma revisão no assunto. Quando eu via algum livro que tivesse qualquer assunto relacionado com o vestibular eu o lia. Meu namorado até brigava comigo por que eu chegava a casa dele e fazia isso.

Na minha cidade, a UFPA só oferta cursos de licenciaturas: Pedagogia e Letras, mas naquele ano ofertaram Ciências Naturais em virtude de a Prefeitura da cidade investir na reciclagem dos professores da rede pública. Como existia toda uma infra-estrutura e que provavelmente ficaria abandonada, a UFPa ofertou o curso a todos, foi então que eu o escolhi. Quando eu soube que era o curso mais concorrido senti muito medo.

$\mathrm{O}$ dia da primeira fase chegou, e no final da prova quando fui conferir o meu gabarito conferi 21 acertos. Fiquei muito decepcionada, pois tinha estudado bastante. No dia seguinte, todos no cursinho falavam da sua pontuação e a maioria tinha feito mais pontos que eu, mesmo assim passei à fase seguinte. Na segunda na fase fui melhor, fiz mais acertos, ainda assim imaginava que não iria conseguir.

No dia da última prova, tentei ficar tranqüila para fazer uma boa prova, mas minha redação me deixou preocupada.

O resultado acabou saindo um dia antes do esperado. Acordei cedo, liguei o rádio e fique esperando, estava muito ansiosa, ficava mudando a sintonia do rádio pra ver se ainda não havia saído na outra emissora. Nesse dia eu estava sozinha em casa, meus pais e meu irmão, que ainda estava vivo estavam viajando, quando de repente ouvi o locutor falar que 
estava direto de Belém com o resultado de vestibular. Minhas mãos estavam geladas, trêmulas estava fiquei com medo de passar mal e não ter ninguém pra me socorrer. O locutor começou a anunciar os nomes e como é em ordem alfabética, tinha que esperar, tremia cada vez mais, batia um desespero, pensava se eu teria conseguido.

Quando chegou à letra $M$ houve uma falha na transmissão. Logo depois voltou ao normal e o primeiro nome que eu ouvi foi o meu Marlúcia Gomes dos Santos. Comecei a chorar, o ar faltou, a voz não saiu e não tinha ninguém pra me abraçar. Não sabia o que fazer. Quando eu me acalmei peguei liguei para o meu irmão e ele avisou meus pais, mas meu pai não falou comigo e nem sequer me deu os parabéns. Nesse dia eu senti tanta coisa: uma grande alegria, alivio por ter passado e uma grande tristeza por ter recebido essa notícia sozinha e não ter visto a face do meu pai naquele momento.

\section{E Agora!}

Depois do resultado começaram as dúvidas, medos, angústias sobre o que é a universidade. Será que e tão difícil como falam? Será que eu vou conseguir? Às vezes eu nem dormia pensando nessas coisas.

O Curso de Ciências Naturais possuía disciplinas da área de exatas que exigem muita dedicação, por isso Fiquei com medo de não conseguir acompanhar. Comecei a pensar se tinha escolhido o curso certo. Estava literalmente com medo. As disciplinas estudadas no curso eram difíceis a meu ver. Felizmente essa fase passou, superei todos meus medos e adoro meu curso. Pretendo ser uma excelente professora de ciências. Não quero ser o chamado professor tradicional, aquele que apenas transmitir o conteúdo para o aluno não se importando com as questões sociais, culturais e econômicos formando não só um aluno mais também um cidadão.

Hoje esse curso representa o meu futuro e o futuro de muitos estudantes, pois o vejo como um mecanismo de mudança tanto do ensino como da sociedade, além de ser uma oportunidade de ter uma vida financeira melhor.

\section{Conexões}

A minha entrada no programa de extensão Conexões de Saberes, não podia vir numa hora melhor. Estava passando por um momento difícil em casa. Tinha um namorado de 4 anos e meu pai não me queria mais em casa. Queria que eu fosse morar com o meu namorado, dizia que já estava na hora de procurar meu rumo, mandou então eu sair de casa. Não era a primeira vez que ele fazia isso. 
Após dois dias do ocorrido o Marielson coordenador do Programa Conexões de Saberes - Campus de Breves bateu na porta de casa me comunicando que teria de comparecer a entrevista para a seleção de bolsista do programa. Coloquei as mãos para o céu e agradeci a Deus, pois isso não poderia ocorrer em momento melhor. Era uma oportunidade de renda e se eu conseguisse talvez meu pai não me colocaria para fora de casa pois, não daria mais gastos para ele. Felizmente consegui a bolsa, continuei em casa e meu pai passou a me tratar melhor.

Quando iniciei minhas atividades no programa conexões não sabia exatamente o que era, o que eu iria fazer naquele espaço. Com o tempo, fui me familiarizando e entendo o objetivo e a importância do programa enquanto meio oportuno de acesso e permanência de estudantes de origem popular nas universidades públicas, visto que esses são os que mais tem dificuldades de ingressarem na mesma, por causa desse sistema desigual que existe em nosso país. E o programa por ser de iniciativa federal vem demonstrar como essa desigualdade e preocupante e tem que ser combatida, e não há melhor maneira do que a educação.

No conexões aprendi muita coisas, passei a ter um olhar mais crítico sobre os problemas sociais, coisa que eu não fazia, e de certa forma me colocando dentro do problema e tentando fazer o possível para resolvê-lo. Uma atividade realizada pelo projeto que demonstra essa preocupação foi o cursinho popular, que é uma oportunidade não só para alunos da rede pública que não tem condições de pagar um curso preparatório, como para aquelas pessoas que já concluíram o ensino médio e ainda não tiveram um oportunidade.

Eu como acadêmica do curso de licenciatura Plena em Ciências Naturais pretendo ser uma professora que consiga formar alunos prontos para o vestibular, e prontos como cidadãos, e que sejam agentes de transformações dessa sociedade desigual. 